\title{
Mapping and ranking global mortality, affected population and GDP loss risks for multiple climatic hazards
}

\author{
SHI Peijun ${ }^{1,2,3}$, YANG Xu ${ }^{1,3}$, FANG Jiayi ${ }^{1,3}$, WANG Jing'ai ${ }^{2,4}$, XU Wei ${ }^{2,3}$, \\ HAN Guoyi ${ }^{1,3}$
}

1. State Key Laboratory of Earth Surface Processes and Resource Ecology, Beijing Normal University, Beijing 100875, China;

2. Key Laboratory of Environmental Change and Natural Disasters of Ministry of Education, Beijing Normal University, Beijing 100875, China;

3. Academy of Disaster Reduction and Emergency Management, Ministry of Civil Affairs and Ministry of Education, Beijing 100875, China;

4. Key Laboratory of Regional Geography, Beijing Normal University, Beijing 100875, China

\begin{abstract}
Coping with extreme climate events and its related climatic disasters caused by climate change has become a global issue and drew wide attention from scientists, policy-makers and public. This paper calculated the expected annual multiple climatic hazards intensity index based on the results of nine climatic hazards including tropical cyclone, flood, landslide, storm surge, sand-dust storm, drought, heat wave, cold wave and wildfire. Then a vulnerability model involving the coping capacity indicator with mortality rate, affected population rate and GDP loss rate, was developed to estimate the expected annual affected population, mortality and GDP loss risks. The results showed that: countries with the highest risks are also the countries with large population or GDP. To substantially reduce the global total climatic hazards risks, these countries should reduce the exposure and improving the governance of integrated climatic risk; Without considering the total exposure, countries with the high mortality rate, affected population rate or GDP loss rate, which also have higher or lower coping capacity, such as the Philippines, Bangladesh and Vietnam, are the hotspots of the planning and strategy making for the climatic disaster risk reduction and should focus on promoting the coping capacity.
\end{abstract}

Keywords: climatic disaster; multiple climatic hazards; mortality risk; affected population risk; GDP loss risk

\section{Introduction}

Natural disasters that are now increasing in scale and more frequent in occurrence, together

Received: 2015-12-23 Accepted: 2016-03-15

Foundation: The Innovative Research Group Project of National Natural Science Foundation of China, No.41321001; The National Basic Research Program (973 Program), No.2012CB955404; The Program for Introducing Talents of Disciplines to Universities funded by the Ministry of Education and State Administration of Foreign Experts Affairs, China, No.B08008

Author: Shi Peijun (1959-), PhD and Professor, specialized in natural hazards, global environmental change, insurance, risk governance, natural resources, and land use policy. E-mail: spj@bnu.edu.cn 
with climate change, significantly impede progress towards sustainable development (UNISDR, 2015). According to the statistics by World Meteorological Organization (WMO), 7870 climatic disaster events occurred during 1970-2009, which led to nearly 1.86 million in casualties and 1954 billion in direct economic losses (WMO, 2013). The climatic disasters with top 10 casualities only accounted for $0.1 \%$ of the total number but for $70 \%$ of the total casualities, and direct economic losses in the top 10 of climatic disasters accounted for $19 \%$ of the total losses (WMO, 2013). Even though, there is a decreasing trend in casualties which caused by extreme weather events and climatic hazards has been observed in recently years, the economic loss is still increasing. Aiming at this, the United Nations Development Programme (UNDP) came up with the Sendai Framework for Disaster Risk Reduction 2015-2030 (SFDRR) including seven targets to support the assessment of global disaster risk reduction progress during 2020-2030 (UNISDR, 2015). Coping with extreme climate events and its related climatic disasters caused by climate change has become a global issue and drew wide attention from scientists, policy-makers and the public (IPCC, 2014).

To provide scientific support for disaster risk reduction policy-makers, many researchers and institutions are focusing on the assessment of mortality, affected population or the economic loss risks of global multiple climatic hazards from macro perspectives. The risk assessment of multiple natural hazards aims at assessing the total risk of various types of natural hazards happening in a given region and in a certain period of time (Shi, 2009). Globally, analyzing the spatial patterns and changes in natural hazards has been pivotal to tackle global climate change and to formulate integrated risk governance policies. More and more risk assessments of integrated natural disasters have been carried out by international organizations and agencies (UNDP, 2004; Dilley et al., 2005; UNU, 2013; JRC, 2014; Shi and Kasperson, 2015). In view of climatic hazards, however, there is few study about integrated climatic disaster risk research from the perspective of multi-hazards (Xu et al., 2016), plenty of studies mainly aim at single hazard (e.g., Peduzzi et al., 2012; Jongman et al., 2012), For instance, based on historical disasters data from 1994 to 2013 of five climatic hazards (storms, floods, mass movements, heat and cold waves), by the Germanwatch program developed German Federal Ministry for Economic Cooperation and Development (BMZ) ranked the countries according to casualties, mortality rate, GDP loss and GDP loss rate, then calculated Global Climate Risk Index (CRI) by using weighting method according to the following weighting: death toll, $1 / 6$; deaths per 100,000 inhabitants, 1/3; absolute losses in Purchasing Power Parity (PPP), 1/6; losses per GDP unit, 1/3 (Kreft et al., 2014).

Above all, the existing single climatic hazard research is not enough for strategic planning of integrated risk governance and decision-making. While the existing risk assessment of multiple climatic hazards just based on statistics analysis of several historical climatic hazards, it is difficult to capture spatio-temporal patterns of a variety of climatic hazards, to reflect the impact of climatic disaster to human society objectively. According to the key risks of global climate change (IPCC, 2014), eight climatic drivers of impacts, include warming trend, extreme temperature, drying trend, extreme precipitation, precipitation, snow cover, damaging cyclone and sea level rising are considered. Thus, nine climatic hazards, include tropic cyclone, flood, landslide, storm surge, sand-dust storm, drought, heat wave, cold wave and wildfire are chosen in this study. A vulnerability assessment model is built to calculate the expected annual affected population, mortality and GDP loss risks, which can provide 
scientific support for managing future risks, building resilience, governing the integrated risk and evaluating the implementation of SFDRR from macro perspectives.

\section{Datasets and methods}

Based on the expected annual natural multi-hazard intensity method in the World Atlas of Natural Disaster Risk, the expected annual multiple climatic hazards intensity index $\left(M_{c h}\right)$ is calculated. The vulnerability assessment model (binary linear regression model) among, the coping capacity indicator (GDP per capita or population) and the mortality rate, affected population rate or GDP loss rate is developed to assess risks. Figure 1 shows the flowchart for calculating the global affected population, mortality and GDP loss risks for multiple climatic hazards.

\subsection{Data}

The datasets used in this study are listed in Table 1.

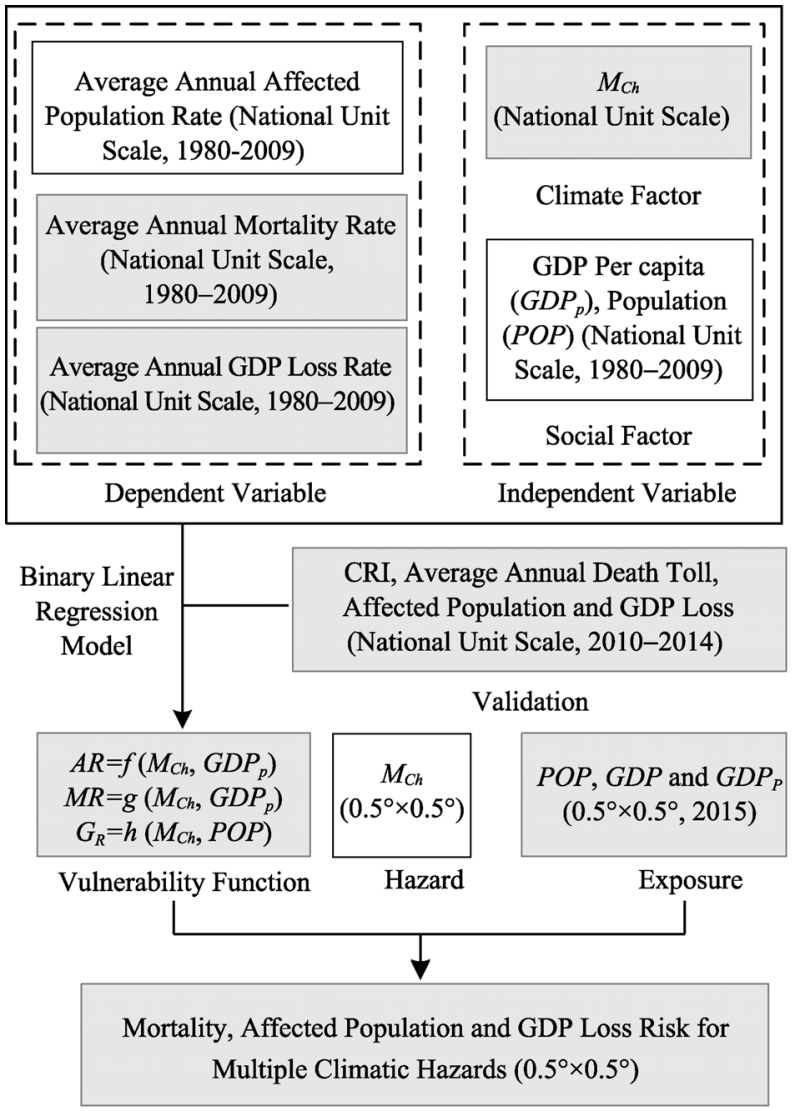

Figure 1 Technical flowchart for calculating the global affected population, mortality and GDP loss risks for multiple climatic hazards

Table 1 Sources and descriptions of the data

\begin{tabular}{llll}
\hline \multicolumn{1}{c}{ Dataset } & \multicolumn{1}{c}{ Data source } & Resolution & Time \\
\hline $\begin{array}{l}\text { Climatic Hazards Intensity } \\
\text { Indexes }\end{array}$ & $\begin{array}{l}\text { World Atlas of Natural Disaster Risk } \\
\text { (Shi and Kasperson, 2015) }\end{array}$ & $0.5^{\circ} \times 0.5^{\circ}$ & $\begin{array}{l}\text { Annual } \\
\text { expectation }\end{array}$ \\
$\begin{array}{l}\text { Global Climate Risk Index } \\
\text { (CRI) }\end{array}$ & $\begin{array}{l}\text { German Federal Ministry for Economic } \\
\text { Cooperation and Development (BMZ) } \\
\text { Germanwatch Program }\end{array}$ & $\begin{array}{l}\text { Country } \\
\text { unit }\end{array}$ & $1994-2013$ \\
Lack of Coping Capacity Index & $\begin{array}{l}\text { European Commission's Joint Research } \\
\text { (LCCI) }\end{array}$ & Country (JRC) INFORM model & 2015 \\
$\begin{array}{l}\text { Death Toll and Affected } \\
\text { Population }\end{array}$ & Emergency Events Database (EM-DAT) & Country & $1980-2014$ \\
$\begin{array}{l}\text { Population and GDP density } \\
\text { (Grid unit) }\end{array}$ & $\begin{array}{l}\text { Greenhouse Gas Initiative (GGI) Program } \\
\text { of the International Institute for Applied }\end{array}$ & 0.5 $\times 0.5^{\circ}$ & 2000,2010 \\
Total Population and GDP & Systems Analysis (IIASA) & and 2020* \\
(Country unit) & World Bank & Country & $1980-2014$ \\
\hline
\end{tabular}

*Note: In the GGI database, the time interval of population and GDP density data is ten years, therefore the population and GDP density data in 2015 is represented by the average values of 2010 and 2020 . These density data have converted to the population data and GDP data before we used it to calculate, map or rank the risks. 


\subsection{Methods}

The method is derived from the expected annual intensity indexes of tropical cyclone, landslide, flood, storm surge, sand-dust storm, drought, heat wave, cold wave and wildfire based on the result in the World Atlas of Natural Disaster Risk (shown in Table 2).

Table 2 Hazard intensity index and weights of each hazard when calculating $M_{c h}$ (Shi and Kasperson, 2014)

\begin{tabular}{lllc}
\hline$i$ & Climatic hazards & \multicolumn{1}{c}{ Expected annual intensity index ${ }^{*}$} & Weight (\%) \\
\hline 1 & Flood & Expected annual accumulated three-day extreme precipitation $(\mathrm{mm})$ & 45.21 \\
2 & Tropic cyclone & Expected annual speed of 3s gust wind $(\mathrm{m} / \mathrm{s})$ & 36.89 \\
3 & Landslide & Expected annual landslide hazard index & 6.96 \\
4 & Drought (maize) & Expected annual normalized cumulative water stress index during & 2.51 \\
& Drought (wheat) & the crop's growing season & 0.63 \\
& Drought (rice) & & 2.09 \\
5 & Heat wave & Expected annual maximum temperature $\left({ }^{\circ} \mathrm{C}\right)$ & 1.74 \\
6 & Cold wave & Expected annual largest temperature drop $\left({ }^{\circ} \mathrm{C}\right)$ & 1.61 \\
7 & Wildfire (forest) & Expected annual ignition probability of forest wildfire $(\%)$ & 1.03 \\
& Wildfire(grassland) & Expected annual ignition probability of grassland wildfire $(\%)$ & 0.61 \\
9 & Storm surges & Expected annual maximum inundation area $\left(\mathrm{km}{ }^{2}\right)$ & 0.51 \\
\hline
\end{tabular}

*Note: The expected annual intensity index is an absolute value outputted at grid unit $\left(0.5^{\circ} \times 0.5^{\circ}\right)$, which can be calculated by hazard intensity value in different return period or the analysis of historical disaster data. e.g., the expected annual accumulated three-day extreme precipitation of flood is calculated by the extreme value analysis of global daily precipitation data; the expected annual speed of $3 \mathrm{~s}$ gust wind of tropic cyclone is calculated by the historical disaster data analysis using Gumbel distribution; the equation to calculate the expected annual landslide hazard index is $I=12.45 D^{-0.42}$, where $D$ is the rainfall duration (h). (Hong et al., 2006); the equation to calculate the expected annual normalized cumulative water stress index during the crop's growing season is $H I=\sum_{i=1}^{n}\left(W S_{i}\right) / \max (H I)$, where $H I$ is the expected annual normalized cumulative water stress index; $W S_{i}$ is the water stress value on the $i$ day; $n$ is the number of days affected by water stress within the growing season; the expected annual maximum temperature and expected annual largest temperature drop are calculated by the historical disaster data analysis using Weibull distribution; the expected annual ignition probability of grassland wildfire is calculated by the historical disaster data analysis using binomial distribution; the expected annual ignition probability of forest wildfire, the expected annual maximum inundation area of storm surges and the expected annual energy of sand-dust storm are calculated by the fuzzy mathematics using the method of information diffusion(Huang 1997).Detail can be found in the World Atlas of Natural Disaster Risk.

Eq. (1) shows the method for calculating the following.

$$
M_{c h}=\sum_{i=1}^{n} \frac{h_{i}-h_{\text {imin }}}{h_{\text {imax }}-h_{\text {imin }}} \times w_{i}
$$

where $h_{i}$ is the expected annual intensity of hazard $i$ (Shi and Kasperson, 2014); $h_{\text {imin }}$ and $h_{\text {imax }}$ are the minimum and maximum values of $h_{i}$, respectively; $w_{i}$ is the weight of hazard $i$, and is defined by the frequency ratio in the EM-DAT database (1950-2013) (EM-DAT, 2013), and Chinese Catastrophe Database (1949-2009) (Zheng, 2009); and $n$ is the number of climatic hazards. Compared with the above existing multi-hazards risk models, it can characterize and normalize the spatio-temporal pattern and intensity of various climatic hazards.

Vulnerability is a measure of both the sensitivity of population to natural hazards and its 
ability to respond to and recover from the impacts of those hazards (Cutter, 2006). Generally, the vulnerability model can be defined as a function including the coping capacity (social factor) and the natural hazards (natural factor) (Esty DC et al., 2005; UN, 2004; UNU, 2013; Cutter, 2008). European Commission's Joint Research Centre (JRC) developed the INFORM model by choosing 13 indicators, such as government effectiveness, corruption perception index, adult literacy rate, to calculate the Lack of Coping Capacity Index (LCCI) for 191 countries (JRC, 2014). Although lots of existing researches developed a series evaluating results of coping capacity indexes, it is still not available at grid scale. According to the comparison of the coping capacity indexes and GDP per capita, a significant correlation is found between GDP per capita (GDPp) and the LCCI at the 0.01 confidence level (bilateral) with Pearson correlation coefficients of -0.719 . Thus, in this study, $G D P_{p}$ was selected as the representative indicator of the coping capacity factor. $M_{c h}$ was selected as the representative indicator of the climatic hazard factor.

The vulnerability model is developed by considering the coping capacity factor $\left(G D P_{p}\right)$, mortality rate, affected population rate and GDP loss rate, as shown in Eqs. (2) to (4).

$$
\begin{gathered}
M_{R}=f\left(M_{c h}, G D P_{p}\right) \\
A_{R}=g\left(M_{c h}, G D P_{p}\right) \\
G_{R}=h\left(M_{c h}, G D P_{p}\right)
\end{gathered}
$$

where $M_{R}$ is the mortality rate; $A_{R}$ is the affected population rate; $G_{R}$ is the GDP loss rate.

To build the vulnerability model, the historical mortality and total affected population data in the EM-DAT disaster database between 1980 and 2009 were selected as the training sample to estimate the parameters of the binary linear regression model. The significance of the regression equation is at the 0.01 confidence level $(\mathrm{N}=133)$, as shown in Eqs. (5) to (7).

$$
\begin{gathered}
\ln \left(M_{R}\right)=-1.32 \times 10^{-5} \times G D P_{p}+6.10 \times \overline{M_{c h}}-15.48 \\
\ln \left(A_{R}\right)=-1.28 \times 10^{-5} \times G D P_{p}+7.20 \times \overline{M_{c h}}-7.77 \\
\ln \left(G_{R}\right)=-1.02 \times 10^{-5} \times G D P_{p}+8.30 \times \overline{M_{c h}}-7.69
\end{gathered}
$$

where $\overline{M_{c h}}$ is the average value of the country or region.

We used the expected annual loss to express the risk for multiple climatic hazards at grid scale, as shown in Eqs. (8) to (10).

$$
\begin{aligned}
& R_{M}=P O P_{\text {grid }} \times e^{\left(-1.32 \times 10^{-5} \times G D P_{p}+6.10 \times \overline{M_{c h}}-15.48\right)} \\
& R_{A}=P O P_{\text {grid }} \times e^{\left(-1.28 \times 10^{-5} \times G D P_{p}+7.20 \times \overline{M_{c h}}-7.77\right)} \\
& R_{G}=G D P_{\text {grid }} \times e^{\left(-1.02 \times 10^{-5} \times G D P_{p}+8.30 \times \overline{M_{c h}}-7.69\right)}
\end{aligned}
$$

where $R_{M}$ is the expected annual mortality risk for multiple climatic hazards (people per year); $R_{A}$ is the expected annual affected population risk for multiple climatic hazards (people per year); $R_{G}$ is the expected annual GDP loss risk for multiple climatic hazards (USD per year); $G D P_{\text {grid }}$ is GDP data at grid scale; and $P O P_{\text {grid }}$ is the population data at grid scale. 


\section{Result}

Based on Eqs. (5) to (7), the population data $\left(0.5^{\circ} \times 0.5^{\circ}\right)$, GDP data $\left(0.5^{\circ} \times 0.5^{\circ}\right)$ (IIASA, 2005), and $M c h$ data $\left(0.5^{\circ} \times 0.5^{\circ}\right)$ (Shi and Kasperson, 2015) are used to calculate the global expected annual mortality rate, affected population rate and GDP loss rate for multiple climatic hazards by GIS tools. The results are presented in a series of maps at grid unit scale $\left(0.5^{\circ} \times 0.5^{\circ}\right)$ (shown in Figures $2-4$ ) and a table for top 15 countries (about $10 \%$ of the total countries) ranks at national unit scale in descending order (shown in Table 3 ). Then the total risks for multiple climatic hazards can be calculated by overlaying the exposure data. The results are presented in a table for top 15 countries ranks at national unit scale in descending order (shown in Table 4).

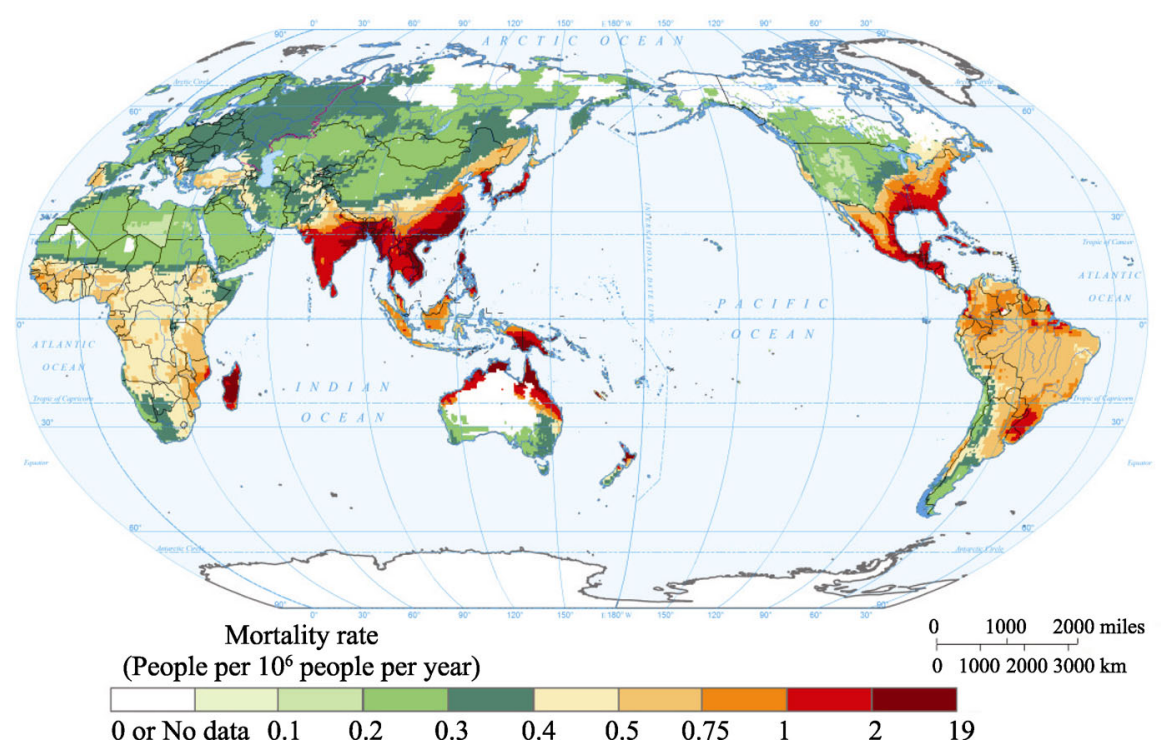

Figure 2 Global expected annual mortality rate for multiple climatic hazards

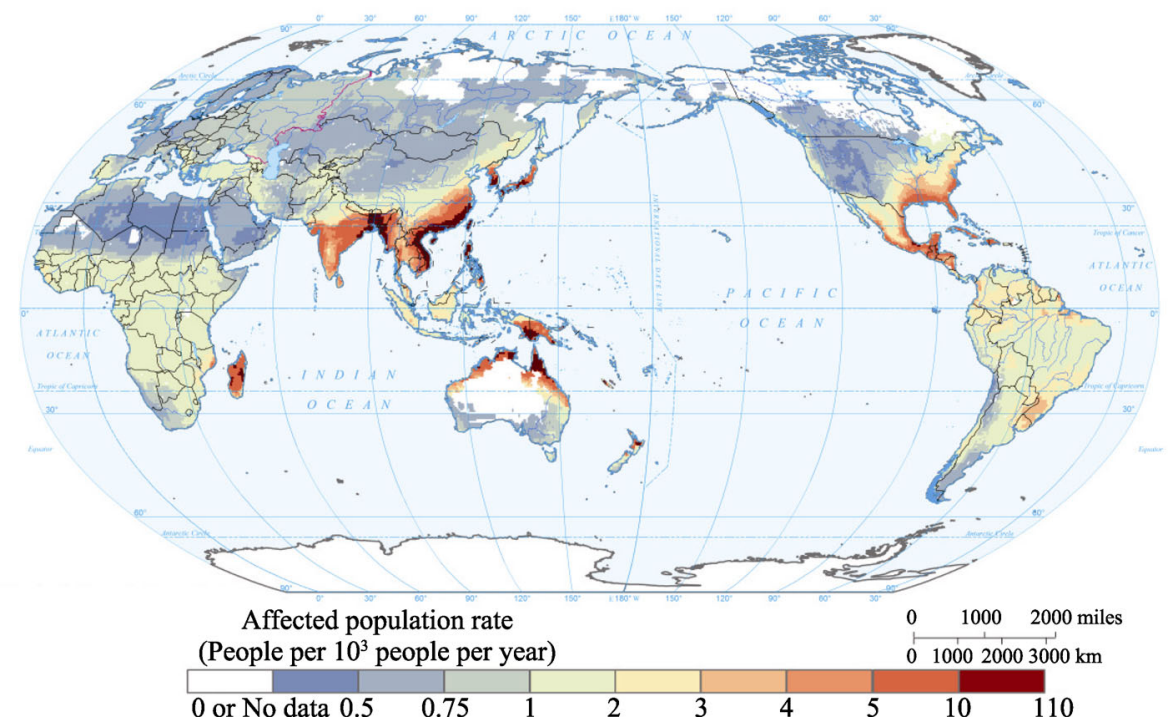

Figure 3 Global expected annual affected population rate for multiple climatic hazards 


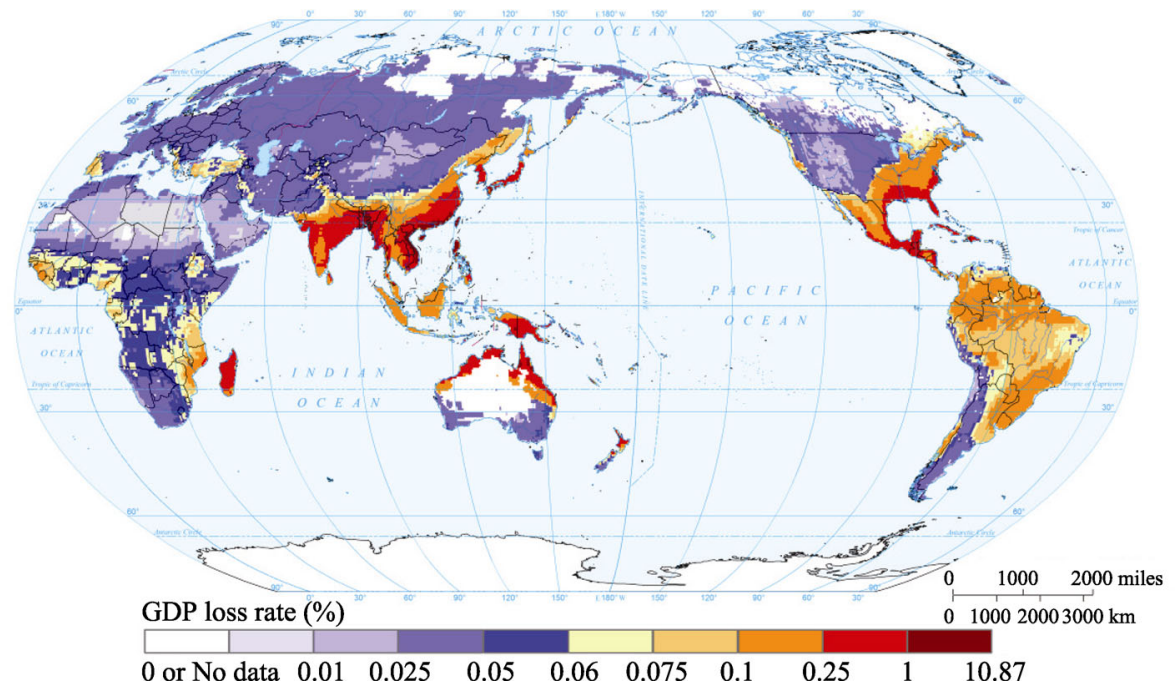

Figure 4 Global expected annual GDP loss rate for multiple climatic hazards

Table 3 Top 15 countries with the highest expected annual mortality rate, affected population rate and GDP loss rate for multiple climatic hazards

\begin{tabular}{|c|c|c|c|c|c|c|c|c|}
\hline \multicolumn{3}{|c|}{ Expected annual mortality rate } & \multicolumn{3}{|c|}{ Expected annual affected population rate } & \multicolumn{3}{|c|}{ Expected annual GDP loss rate } \\
\hline Rank & Country & $\begin{array}{l}\text { Per million } \\
\text { people per } \\
\text { year }\end{array}$ & Rank & $\begin{array}{l}\text { Country } \\
\text { name }\end{array}$ & $\begin{array}{c}\text { Per thousand } \\
\text { people per year }\end{array}$ & Rank & Country & $\begin{array}{c}\text { Per year } \\
(\%)\end{array}$ \\
\hline 1 & Philippines & 6.87 & 1 & Philippines & 31.55 & 1 & Philippines & 7.53 \\
\hline 2 & Bangladesh & 4.16 & 2 & Bangladesh & 16.14 & 2 & Bangladesh & 3.05 \\
\hline 3 & Vietnam & 3.56 & 3 & Vietnam & 13.83 & 3 & Vietnam & 2.68 \\
\hline 4 & Laos & 2.61 & 4 & Laos & 9.49 & 4 & Bhutan & 1.66 \\
\hline 5 & South Korea & 2.47 & 5 & South Korea & 8.98 & 5 & $\begin{array}{l}\text { New } \\
\text { Caledonia }\end{array}$ & 1.66 \\
\hline 6 & Madagascar & 2.40 & 6 & $\begin{array}{c}\text { New Cale- } \\
\text { donia }\end{array}$ & 8.91 & 6 & Lao PDR & 1.62 \\
\hline 7 & Belize & 2.38 & 7 & Belize & 8.49 & 7 & Korea, Rep. & 1.62 \\
\hline 8 & $\begin{array}{l}\text { New } \\
\text { Caledonia }\end{array}$ & 2.38 & 8 & Madagascar & 8.47 & 8 & Japan & 1.60 \\
\hline 9 & $\begin{array}{l}\text { Dominican } \\
\text { Republic }\end{array}$ & 2.08 & 9 & Japan & 8.13 & 9 & Madagascar & 1.53 \\
\hline 10 & Japan & 2.08 & 10 & $\begin{array}{l}\text { Dominican } \\
\text { Republic }\end{array}$ & 7.19 & 10 & Belize & 1.50 \\
\hline 11 & Burma & 2.02 & 11 & Burma & 7.08 & 11 & China & 1.33 \\
\hline 12 & $\begin{array}{l}\text { Papua New } \\
\text { Guinea }\end{array}$ & 1.88 & 12 & $\begin{array}{c}\text { Papua New } \\
\text { Guinea }\end{array}$ & 6.40 & 12 & $\begin{array}{l}\text { Dominican } \\
\text { Republic }\end{array}$ & 1.24 \\
\hline 13 & Guatemala & 1.76 & 13 & Bhutan & 6.09 & 13 & Myanmar & 1.16 \\
\hline 14 & Bhutan & 1.75 & 14 & Guatemala & 5.86 & 14 & $\begin{array}{l}\text { Papua New } \\
\text { Guinea }\end{array}$ & 1.12 \\
\hline 15 & North Korea & 1.60 & 15 & China & 5.44 & 15 & Guatemala & 0.94 \\
\hline
\end{tabular}

\section{Validation}

To validate the model result of affected population and mortality risk, the total affected population, mortality data in the EM-DAT historical disaster database between 2010 and 2014 were selected as the validation sample (shown in Figures 5 and 6). 
Table 4 Top 15 countries with the highest total expected annual mortality risk, affected population risk and GDP loss risk for multiple climatic hazards

\begin{tabular}{|c|c|c|c|c|c|c|c|c|}
\hline \multicolumn{3}{|c|}{ Total expected annual mortality risk } & \multicolumn{3}{|c|}{$\begin{array}{l}\text { Total expected annual affected } \\
\text { population risk }\end{array}$} & \multicolumn{3}{|c|}{$\begin{array}{l}\text { Total expected annual GDP } \\
\text { loss risk }\end{array}$} \\
\hline Rank & Country & $\begin{array}{l}\text { People } \\
\text { Per year }\end{array}$ & Rank & $\begin{array}{l}\text { Country } \\
\text { Name }\end{array}$ & $\begin{array}{l}\text { Million peo- } \\
\text { ple per Year }\end{array}$ & Rank & Country & $\begin{array}{c}\text { Billion } \\
\text { USD Per } \\
\text { year }\end{array}$ \\
\hline 1 & India & 2194 & 1 & China & 7.89 & 1 & China & 75.85 \\
\hline 2 & China & 2181 & 2 & India & 7.25 & 2 & Japan & 74.93 \\
\hline 3 & Bangladesh & 927 & 3 & $\begin{array}{c}\text { Bangla- } \\
\text { desh }\end{array}$ & 3.60 & 3 & $\begin{array}{l}\text { United } \\
\text { States }\end{array}$ & 49.14 \\
\hline 4 & Philippines & 726 & 4 & $\begin{array}{l}\text { Philip- } \\
\text { pines }\end{array}$ & 3.34 & 4 & Philippines & 23.47 \\
\hline 5 & Vietnam & 374 & 5 & Vietnam & 1.46 & 5 & India & 11.57 \\
\hline 6 & United States & 243 & 6 & Japan & 0.95 & 6 & Korea, Rep. & 5.96 \\
\hline 7 & Japan & 242 & 7 & $\begin{array}{l}\text { United } \\
\text { States }\end{array}$ & 0.79 & 7 & Mexico & 4.08 \\
\hline 8 & Indonesia & 181 & 8 & Indonesia & 0.51 & 8 & Brazil & 3.73 \\
\hline 9 & Brazil & 156 & 9 & Mexico & 0.47 & 9 & Vietnam & 3.72 \\
\hline 10 & Mexico & 152 & 10 & $\begin{array}{l}\text { South } \\
\text { Korea }\end{array}$ & 0.46 & 10 & Bangladesh & 2.90 \\
\hline 11 & South Korea & 126 & 11 & Brazil & 0.44 & 11 & Indonesia & 2.52 \\
\hline 12 & Burma & 125 & 12 & Burma & 0.44 & 12 & Thailand & 2.46 \\
\hline 13 & Pakistan & 122 & 13 & Thailand & 0.33 & 13 & Germany & 2.36 \\
\hline 14 & Nigeria & 110 & 14 & Pakistan & 0.32 & 14 & Myanmar & 2.13 \\
\hline 15 & Thailand & 104 & 15 & Nigeria & 0.29 & 15 & France & 1.87 \\
\hline
\end{tabular}

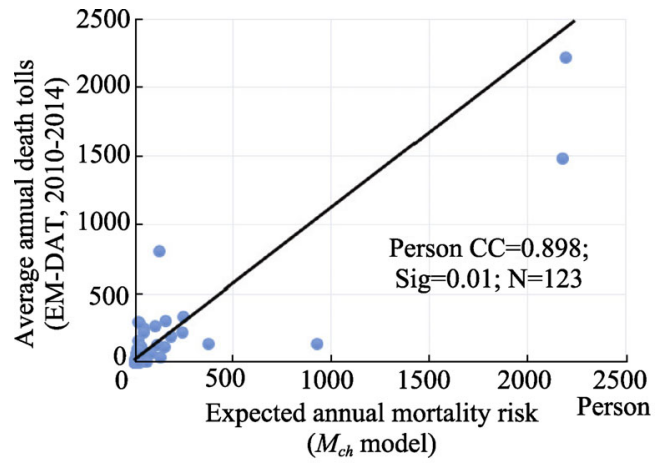

Figure 5 Comparison of the expected annual mortality risk (model) and the historical disaster data in EM-DAT

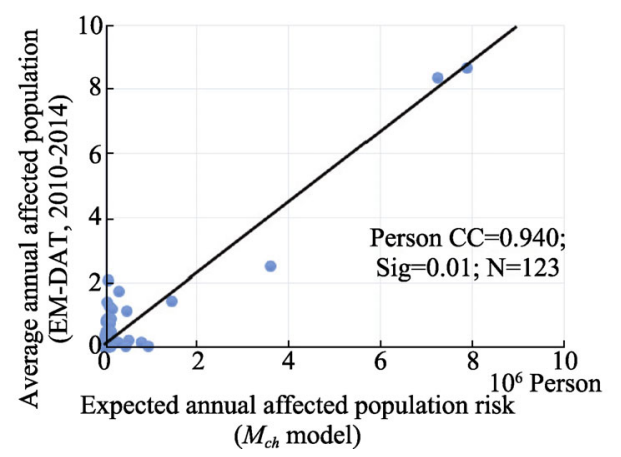

Figure 6 Comparison of the expected annual affected population risk (model) and the historical disaster data in EM-DAT

A significant correlation between the result of the model and the real affected population, mortality data in the historical database was found at the 0.01 confidence level (bilateral), with Pearson correlation coefficients of 0.898 (mortality) and 0.940 (affected population).

To validate the model result of GDP loss, the CRI in Germanwatch program was selected as the validation sample. We converted the GDP loss risk and rate to the rank score following the equation of CRI economic loss score and did the Spearman test between two of the result (shown in Figure 7).

A significant Spearman correlation between the result of the model and the economic loss 
score was found at the 0.01 confidence level (bilateral), with Spearman correlation coefficients of 0.737 .

\section{Discussion}

The value of integrated climatic hazards risk at national unit reflects the total level of a country suffered from climatic hazards impacts. It can be seen from Eqs. (8) to (10) that the dominant factors affecting the total mor-

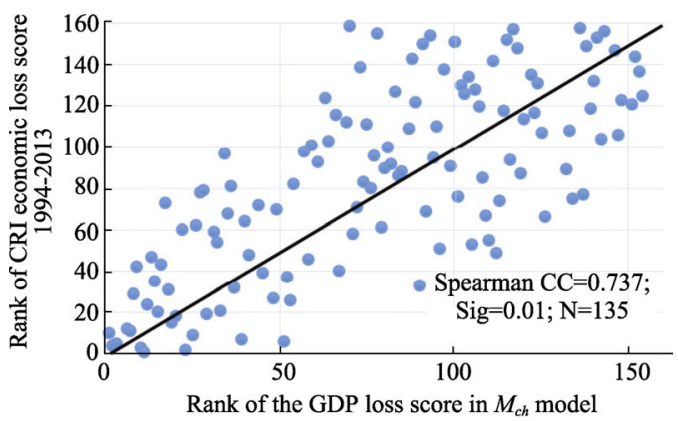

Figure 7 Comparison of the rank of CRI economic loss score and the rank of the GDP loss score in model tality and affected population risk value for multiple climatic hazards include total population (positively correlated), GDP per capita (negatively correlated) and GDP per capita (positively correlated); the main factors affecting the total GDP loss risk value for multiple climatic hazards include GDP (positively correlated), total population (negatively correlated) and total population (positively correlated).The top 15 countries and regions with high total affected population, mortality and GDP loss risks for multiple climatic hazards show that exposure quantity determines ranking of the total risk. Thus, improving integrated risk governance for those countries with large population and economic exposure is an effective way to mitigate the total risks of global population and economy for multiple climatic hazards.

Except the exposure, the ranking of average loss rate can reflect the vulnerability of a country to multiple climatic hazards. It can be seen from loss rate calculation formula Eqs. (5) to (7) that the main factors affecting the total affected population and mortality rate value for multiple climatic hazards include GDP per capita (negatively correlated) and (positively correlated).The top 15 countries and regions with high mortality rate for multiple climatic hazard shows that and the national economic development level (GDP per capita) codetermine the risk ranking. The Philippines, Laos and Vietnam, the three countries in Southeast Asia, with a frequent, strong and wide influence of climatic disasters, have high multiple climatic hazards intensity; Meanwhile, because of the low disaster prevention input level of these three countries, their rankings of global mortality rate, affected population rate and GDP Loss rate are very prominent. Thus, for those developing countries with high value, it is important to improve coping capability and integrated disaster risk governance by enhancing its economic strength or gaining international aid, which would directly reduce mortality and affected population risk. The top 15 countries and regions with high GDP loss for multiple climatic hazard shows that with the gradual perfection of prevention and reduction measures of climatic disasters, it still be easily ignored in those areas with high economic capacity and low population density, make those areas suffer higher economic loss when encounters climatic hazards. Thus, it should be emphasized to improve integrated risk governance in those areas with high economic loss rate, to ensure the sustainability of wealth and productivity.

Based on ranking of affected population, mortality and GDP loss caused by multiple climatic hazards, large population or economy countries, countries with high and countries with low socioeconomic status and low coping capacity are the hotspots for strengthening 
disaster risk governance to manage disaster risk.

\section{Conclusions}

Existing researches of multiple climatic hazards, such as Germanwatch and INFORM, have limitations since these researches only focus on one category of exposure, fewer climatic hazards or qualitative evaluation. The results presented in this study possess high spatial resolution with considering intensity, frequency and spatio-temporal patterns of multiple climatic hazards. Compared with the existing researches, this study carried out a sub-national $\left(0.5^{\circ} \times 0.5^{\circ}\right.$ grid) assessment for multiple climatic hazards (nine hazards are considered) and both population and economic exposure. Meanwhile, this study came up with a series of results considering both the hazards intensity and the coping capability of countries in two ways: the absolute total expected annual risks and the relative rates. Although the accuracy of the result is still needed to be improved, the absolute and relative assessment can both directly provide scientific basis and decision support for establishing global, national and regional climatic disaster prevention and reduction strategies.

However, the results presented here focusing on patterns of multiple climatic hazards and aiming at assessment of affected population, morality and GDP loss risks, are an estimated scenario which is subject to the reliability of population and GDP data (both national and grid unit) since the availability of global data is limited and the quality of disaster and exposure data are difficult to validate. In addition, the changes associated with different hazards as a result of climate change were not considered in this study. Analysis of hazards without considering climate change effects may lead to an underestimation of the impact of such hazards on human society (IPCC, 2012). Meanwhile, the scenario without the social and cultural factors and the dynamic changes in the disaster system is another limitation of the analysis presented here. As to these issues, in addition to acquiring greater amounts of data, further research is needed to explore the mechanism, process and dynamics of earth climatic disaster systems and to develop effective approaches and measures for improving the global capacity for coping with climatic disasters.

\section{References}

Cutter S L, Christina F, 2008. Temporal and spatial changes in social vulnerability to natural hazards. Proceedings of the National Academy of Sciences of the United States of America (PNAS), 105(7): 2301-2306.

Cutter S L, 2006. Hazards, Vulnerability and Environmental Justice. Earthscan.

Dilley M, Deichmann U, Chen R S, 2005. Natural Disaster Hotspots: A Global Risk Analysis. Washington DC: World Bank Publications.

Emergency Events Database (EM-DAT), 2014. Natural Disaster Database. Available from: http://www.emdat.be/. Europe Commission Joint Research Centre (JRC), 2014. Index for Risk Management-INFORM. Luxembourg: EU Esty DC, Levy M, Srebotnjak T, de Sherbinin A, 2005. Environmental Sustainability Index: Benchmarking National Environmental Stewardship (Yale Center for Environmental Law \& Policy, New Haven, CT).

Hong Y, Adler R, Huffman G, 2006. Evaluation of the potential of NASA multi-satellite precipitation analysis in global landslide hazard assessment. Geophysical Research Letters, 33(22).

Huang C F, 1997. Principle of information diffusion. Fuzzy Sets and Systems, 91: 69-90. 
Intergovernmental Panel on Climate Change (IPCC). 2012. IPCC Special Report on Managing the Risks of Extreme Events and Disasters to Advance Climate Change Adaptation (SREX). Cambridge: Cambridge University Press.

IPCC, 2014: Summary for policymakers. In: Climate Change 2014: Impacts, Adaptation, and Vulnerability. UNEP.

International Strategy for Disaster Reduction, 2004. Living with Risk: A Global Review of Disaster Reduction Initiatives (United Nations, New York).

Jongman B, Ward P J, Aerts J C J H, 2012. Global exposure to river and coastal flooding: Long term trends and changes. Global Environmental Change, 22(4): 823-835.

Kreft S, Eckstein D, Junghans L et al., 2014. Global climate risk index 2015: Who suffers most from extreme weather events? Weather-related loss events in 2013 and 1994 to 2013.

Peduzzi P, Chatenoux B, Dao H et al., 2012. Global trends in tropical cyclone risk. Nature Climate Change, 2(4): 289-294.

Shi P J, 2009. Theory and practice on disaster system research: The fifth discussion. Journal of Natural Disasters, 18(5): 1-9. (in Chinese)

Shi P J, 2011. Atlas of Natural Disaster Risk of China. Beijing: Science Press.

Shi P J, Karsperson R, 2015. World Atlas of Natural Disaster Risk. Heidelberg: Springer.

The World Bank Group, 2014. World Bank Open Data. Available from: http://data.worldbank.org.

United Nations Development Programme (UNDP), 2004. Reducing Disaster Risk: A Challenge for Development. New York: UNDP.

United Nations University Institute for Environment and Human Security (UNU-EHS), 2013. World Risk Report (2013).

United Nations International Strategy for Disaster Reduction (UNISDR). 2015. Sendai framework for disaster risk reduction 2015-2030. A/CONF.224/CRP.1. Geneva: UNISDR.

http://www.unisdr.org/files/43291_sendaiframeworkfordrren.pdf. Accessed on 26 January 2016.

World Meteorological Organization (WMO), 2013. Reducing and managing risks of disasters in a changing climate. WMO Bulletin, 62(Special Issue): 23-31.

$\mathrm{Xu}$ W, Zhuo L, Zheng J et al., 2016. Assessment of the casualty risk of multiple meteorological hazards in China. International Journal of Environmental Research and Public Health, 13(2): 222. doi: 10.3390/ijerph 13020222.

Zheng G C, 2009. Significant Historical Epic for Disaster Prevention and Reduction in Sixty-Year of China. Changsha: Hunan People's Publishing House. (in Chinese) 